\title{
Effectual Gold Nanoprobe Sensor for Screening Cow Milk Adulteration in Goat Milk_-Comparison With Conventional PCR
}

\author{
Jose Manuel Llopis Ortiz ${ }^{1,2}$, Christos Tsouknidas ${ }^{1}$, Sophie Pytel ${ }^{1}$, Spiridon Papatheodorou ${ }^{1}$, \\ Despina Vougiouklaki ${ }^{1}$, Aliki Tsakni ${ }^{1}$, Dionysios Antonopoulos ${ }^{1}$, Efstathia Tsakali ${ }^{1,2}$, \\ Jan Van Impe ${ }^{2} \&$ Dimitra Houhoula ${ }^{1}$ \\ ${ }^{1}$ Department of Food Science and Technology, University of West Attica, Athens, Greece \\ ${ }^{2}$ BioTeC+: Chemical and Biochemical Process Technology and Control, Department of Chemical Engineering, \\ KU Leuven, Gent, Belgium \\ Correspondence: Efstathia Tsakali, BioTeC+: Chemical and Biochemical Process Technology and Control, \\ Department of Chemical Engineering, KU Leuven, Gebroeders De Smetstraat 1, 9000 Gent, Belgium. Tel: \\ 306-994-543-717. E-mail: efi.tsakali@kuleuven.be
}

Received: December 27, 2020

Accepted: March 1, $2021 \quad$ Online Published: April 15, 2021

doi:10.5539/jas.v13n5p41

URL: https://doi.org/10.5539/jas.v13n5p41

The present work was co-funded by the European Commission within the framework of the Erasmus + BIFTEC Programme (Erasmus Mundus Joint Master Degree in Food Science, Technology and Business Agreement $N^{\circ}$ 2015-2516-Project $\left.N^{\circ} 564453\right)$ and by the European Union's Horizon 2020 Research and Innovation programme under the Marie Sklodowska-Curie Grant Agreement $N^{\circ} 956126$ (E-MUSE Complex microbial Ecosystems MUltiScale modElling).

\begin{abstract}
Different methods have been used to detect milk adulteration, but in recent years the use of nanomaterials has been introduced as an interesting tool, due to their optical properties. A gold nanoparticle (AuNP) probe application was developed in order to evaluate milk adulteration. The methodology relies on the colorimetric differentiation and the participation profiles of the hybridization DNA sequence with the AuNPs. Various concentrations, from 0.01 (traces) to $50 \%$, of cows' milk in goats' milk samples were prepared for DNA extraction, further identification with the AuNPs and comparison with a conventional PCR. Also, a total of 40 dairy products from goat milk, commonly consumed in Greece, were tested. Negative and goat reaction mixtures showed a purplish coloured solution with a peak at $>570 \mathrm{~nm}$, while samples containing bovine DNA had an absorbance closer to the characteristic peak of the AuNPs at 520-525 nm. Presence of bovine milk was detected even at traces level, achieving a detection level comparable to those achieved by conventional PCR. The use of AuNPs in milk products, provides a low-cost and easy-to-perform method and offers the possibility to detect fraudulent practices in various food matrices.
\end{abstract}

Keywords: food authentication, goat milk adulteration, gold nanoparticles

\section{Introduction}

Food adulteration has always been a major problem of the food industry. Substitution of expensive materials by other ones with lower commercial value or addition of ingredients non-related with the nature of the product, are practices that have been reported and which can cause lack of confidence in the Food Industry (EU Science Hub, 2016).

Natural milk is considered as an important nutritive food, as it is a good source of carbohydrates, fats, proteins, minerals and vitamins (Neumann et al., 2002). Its beneficial effects for mothers, infants, children and elderly people originate from its easy digestibility and absorption, while milk proteins are a significant source of amino acids needed for proper growth (Afzal et al., 2011).

Bovine milk is commonly used for adulteration of other milk kinds because of its predominant production and its lower cost (Borkova \& Snaselova, 2005). The consumption of adulterated milk may affect people with allergies to cow milk components (Cheng et al., 2006; Haenlein, 2004; Pesic et al., 2011), especially since milk proteins, are potential allergens even at low concentrations (Sampson, 2003; Rance et al., 2005). Nowadays, the goat milk 
consumption is increasing in the occidental countries, so this kind of adulteration practices may have a serious impact in public health. Previous studies have shown that adulteration of dairy products with cow milk is a common practice, especially in developing countries (Darwish et al., 2009; Golinelli et al., 2014; Salih \& Yang, 2017).

Due to the aforementioned social and health impact of milk adulteration, there is a vast number of publications about different methods for its detection. Over the time, new methods were introduced, but still the majority of methodologies to identify dairy products' authenticity is based on the study of the major milk proteins (Stanciuc \& Rapeanu, 2010). The techniques used to estimate these differences include non-immunological methods, analysis of fatty acid composition by gas chromatography or the detection of specific protein components by HPLC, SDS-PAGE (polyacrylamide gel electrophoresis) (Lee et al., 2004; Mayer, 2005), and isoelectric focusing (Amigo et al., 1991; Kim \& Jimeez-Flores, 1993; Chen et al., 2004; Enne et al., 2005). All of these methods have the disadvantage of being time consuming and uneconomic. Immunological approaches use an enzyme-linked immunosorbent assay (Anguita et al., 1996; Ritcher et al., 1997; Hurley et al., 2004; Zelenakova \& Golian, 2008); some false positive and false negative results remain to be overcome. PCR (polymerase chain reaction) provides an alternative way of identifying the additions of foreign milk or dairy products to the original milk by analysis of mitochondrial DNA (Bania et al., 2001; Maudet \& Taberlet, 2001; Bottero et al., 2003). PCR is the most widely employed method to identify milk adulteration (Poonia et al., 2016; Das et al., 2016) due to its high level of sensitivity and its excellent repeatability. Researchers have reported that they were able, to detect as low as $0,5 \%$ (Darwish et al., 2009) and 0,1\% (Lopez-Calleja et al., 2004) cow milk in milk of other species.

Over the last years, new strategies for the identification of the origin of food have been introduced, which are related to the development of precise nanoparticle-based probes and are competent for detecting DNA target sequences (Ali et al., 2011, 2012, 2014; Houhoula et al., 2017). Nanotechnology and, especially gold nanoparticles (AuNPs) chemistry, offers innovative opportunities for quick and easy analysis of authenticity, since it is capable to evidence even low level of adulteration, thanks to their particular optical properties (Zeng et al., 2011). AuNPs, have been used effectively as colorimetric sensors for visual identification and they are suggested as a cheaper and simple alternative to other molecular methods since they can to work in different food matrices (Ali et al., 2011, 2012, 2014; Houhoula et al., 2017). The aim of the present study is to demonstrate that functionalized AuNPs can be used for the development of a simple DNA detection procedure for the identification of cow milk adulteration in goat milk, and to compare its sensitivity with the most used PCR method.

\section{Method}

\subsection{Selection and Preparation of Samples}

Cow milk (Bos taurus) samples and goat milk (Capra hircus) samples were acquired directly from animals of a local dairy farm into collection tubes, and were immediately refrigerated. Upon arrival to the laboratory, they were stored at $-18^{\circ} \mathrm{C}$ until use.

A total of 40 milk and dairy products were collected from local super markets in the area of Athens (Greece). The products included 25 packaged goat milk products and 15 goat cheeses of different brands.

Spiked samples were prepared with different concentrations of cow milk in goat milk $(0.01 \%$ (traces), $1 \%, 2 \%$, $5 \%, 10 \%, 20 \%$ and 50\%) and were used as positive controls in order to find the detection limit. Pure goat, sheep, donkey milk and water were used as negative controls.

\subsection{Preparation of Gold Nanoparticle Probes}

Gold colloid nanoparticles (AuNPs) of $20 \mathrm{~nm}$ size, were purchased from BBI Solutions (Cardiff, UK). The AuNPs were conjugated with specific oligonucleotides for cow mitochondrial DNA: sense primer GCCATATACTCTCCTTGGTGACA and antisense primer GTAGGCTTGGGAATAGTACGA (Invitrogen ${ }^{\mathrm{TM}}$, USA). The oligonucleotides were modified with 10xdATP in the 5'-end of the primer and thiolated (Cheng et al., 2006; Lahiff et al., 2001; Kusec et al., 2017). The AuNPs were conjugated with the oligonucleotides by adding 1 $\mathrm{ml}$ of AuNPs into $4 \mathrm{nmol}$ of the oligonucleotides using a previously described protocol by Hill and Mirkin (2006). The solution was initially incubated overnight with the AuNPs using an orbital shaker at room temperature and then phosphate buffer $9 \mathrm{mM}(\mathrm{pH} 7)$ and SDS solution $0.1 \%(\mathrm{w} / \mathrm{v})$ were added in order to prevent aggregation. The total salting buffer needed to reach the final concentration of $0.3 \mathrm{M} \mathrm{NaCl}$ and it was added in six doses over the next 48 hours. After centrifugation, the precipitate was washed twice with $500 \mu$ of $10 \mathrm{mM}$ PBS (pH 7.4), $150 \mathrm{mM} \mathrm{NaCl}$ 0.1\% SDS. The prepared AuNPs solution was stored in glass vials kept in dark place, at room temperature. 
In order, to test the possibility to work only with one primer, part of the nanoprobes were prepared by conjugating only with the sense primer under the same conditions as described above.

The obtained functionalized AuNPs solution was measured with a Spectrophotometer Epoch of BioTek ${ }^{\circledR}$. The maximum absorbance was at 520-530 nm indicating a proper conjugation of the AuNPs with the oligonucleotides.

\subsection{DNA Isolation}

DNA extraction from $1.5 \mathrm{~mL}$ of centrifuged $(10$ minutes at $12000 \times \mathrm{g})$, different milk products, was performed using the NucleoSpin Food ${ }^{\circledR}$ kit (Macherey-Nagel, GmbH \& Co. KG, Germany), according to the manufacturer's instructions with a modification of adding an overnight incubation with the Lysis Buffer and the Proteinase $\mathrm{K}$ at $65{ }^{\circ} \mathrm{C}$ instead of a $30 \mathrm{~min}$ incubation. The extracted DNA was quantified spectrophotometrically at $260 \mathrm{~nm}$.

\subsection{PCR Amplification and Electrophoresis}

PCR was performed in $50 \mu \mathrm{L}$ final volume solution using the Master Mix (KAPA BIOSYSTEMS), according to a previously published protocol by Maskova and Paulickova (2006). The program of the PCR was as follows: an Initial denaturation: $94{ }^{\circ} \mathrm{C}, 10 \mathrm{~min} ; 40$ cycles with the following step-cycle profile: denaturation $94{ }^{\circ} \mathrm{C}, 30 \mathrm{~s}$; annealing $60{ }^{\circ} \mathrm{C}, 30 \mathrm{~s}$; extension $72{ }^{\circ} \mathrm{C}, 30 \mathrm{~s}$; Final extension $72{ }^{\circ} \mathrm{C}, 7 \mathrm{~min}$. The chosen primers amplify cow DNA fragments of the size of $274 \mathrm{bp}$ : forward primer: $5^{\prime}$-GAC CTC CCA GCT CCA TCA AAC ATC TCA TCT TGA TGA AA-3'; reverse primer: 5'-CTA GAA AAG TGT AAG ACC CGT AAT ATA AG-3'. PCR products were separated in $2 \%$ agarose gel, stained with ethidium bromide $(0.5 \mu \mathrm{g} / \mathrm{ml})$ and documented under UV illumination using MiniBIS Pro device (DNR Bio-Imaging Systems Ltd., Israel).

\subsection{Direct Hybridization and Color Detection in Milk Samples of AuNPs}

Hybridization on the extracted DNA from the isolates with the AuNPs thiolated with the oligonucleotides solution was performed by adding $20 \mu \mathrm{l}$ of eluted DNA ( $20 \mu \mathrm{l}$ of water or pure goat, sheep and donkey milk as Negative controls). The first step was $5 \mathrm{~min}$ at $95^{\circ} \mathrm{C}$, made as the denaturation step. Following, the hybridization step included $5 \mathrm{~min}$ at $55^{\circ} \mathrm{C}$ after the addition of $20 \mu \mathrm{l} \mathrm{Au}$-NPs-oligonucleotides solution and $10 \mu \mathrm{l}$ of phosphate buffer prepared as described by Hill \& Mirkin, 2006. The aggregation step followed, included the addition of 8 $\mu \mathrm{HCl} 1 \mathrm{M}$. When the color remained pink, the sample was positive (presence of cow DNA), because the Au-NPs-oligonucleotides hybridized the target DNA sequence and they did not aggregate. When the color turned to purple, the sample was considered negative (no cow DNA), because the AuNPs had not found any DNA sequence to hybridize and they aggregated, causing the color change. Positive and negative controls were used for comparison in all cases. The results could be confirmed by UV-Vis spectroscopic analysis.

\subsection{Direct Application on Food Samples}

In order to obtain an indication of the method's performance on milk and dairy samples, the method was applied with the optimized assay for the detection of adulteration of cow milk in goat milk as referred above. The results were evaluated directly visually and were confirmed further with an absorption spectrum. Also, the samples were compared to those obtained by PCR assays.

\section{Results and Discussion}

The developed method is based on the specific target hybridization of the AuNPs with a specific DNA sequence. In general, colloidal solutions of AuNPs with diameters ranging from 5 to $20 \mathrm{~nm}$ show a pink-red color (Figure 1), due to their optical absorption peak at around $520-525 \mathrm{~nm}$, caused by the collective excitation of the free conduction band electrons of the dispersed particles, known as the surface plasmon resonance (Houhoula et al., 2017; Bohren \& Huffman, 1983; Li \& Rothberg, 2004). 


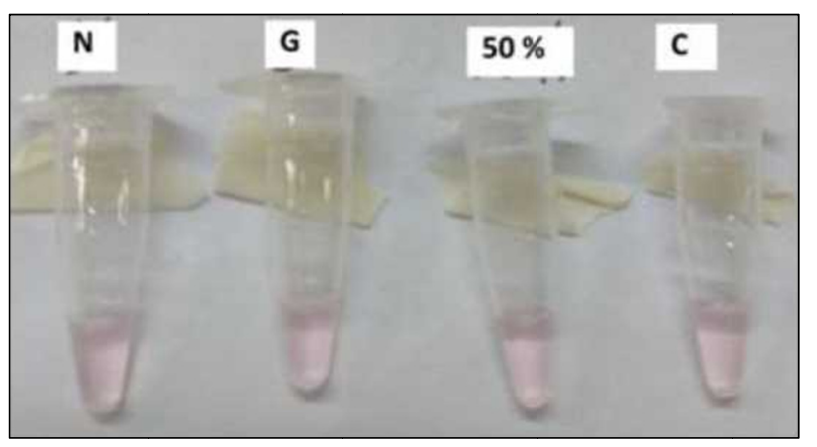

Figure 1. Samples with the characteristic light pink color previous to the addition of $\mathrm{HCl}$ : (1) Negative control- $\mathrm{H}_{2} \mathrm{O}$; (2) Negative control 100\% Goat milk; (3) Goat milk adulterated with $50 \%$ cow milk;

(4) Positive control 100\% cow milk

The aggregation of the AuNPs displaces the absorption peak to a longer wavelength $(>570 \mathrm{~nm})$ and the color of the colloidal solution turns into purple, as a result of the coupling on the surface plasmons of the particles in the aggregates (Sato et al., 2003). Therefore, the degree of aggregation of AuNPs in suspension determines the color of the gold colloid (Quinten and Kreibig, 1986) and this aggregation can be simply induced with the addition of hydrochloric acid (Houhoula et al., 2017). In the presence of the complementary target, the functionalized AuNPs hybridize with the cow DNA and do not aggregate. Therefore, after the addition of $8 \mu \mathrm{lof} \mathrm{HCl}$ the reaction mixture remains with its original pink coloration in the cases of cow DNA presence, whereas the mixture changes to purple, due to the aggregation of the AuNPs in the case of cow DNA absence (Figure 2).

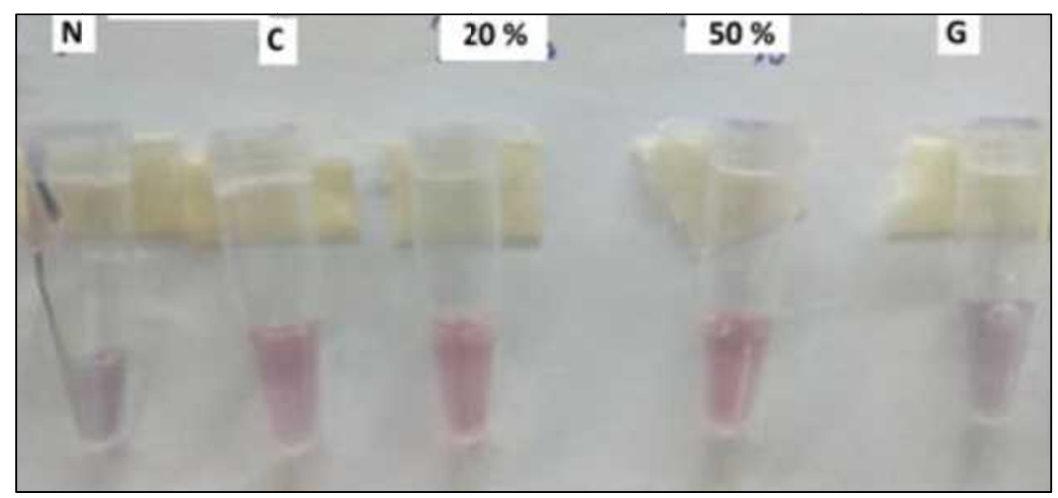

Figure 2. Positive samples exhibit a darker color than the original pink, but still perfectly distinguishable from the purple color of negative samples: (1) Negative control $\mathrm{H}_{2} \mathrm{O}$; (2) Positive control 100\% cow milk;

(3) Goat milk adulterated with $20 \%$ cow milk; (4) Goat milk adulterated with $50 \%$ cow milk;

(5) Negative control 100\% Goat milk

The results were compared with those obtained by PCR assay (Figure 3). 


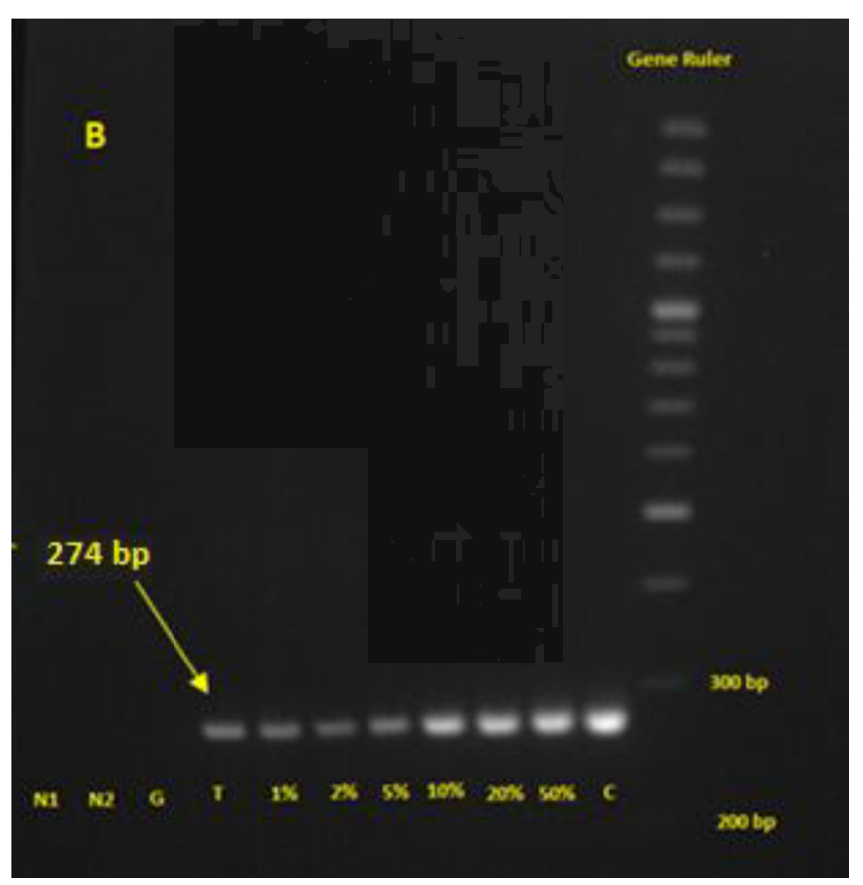

Figure 3. Electrophoretic analysis of the PCR products obtained from DNA extracts of different dilutions of cow milk in goat milk, (1) and (2) Negative control $\mathrm{H}_{2} \mathrm{O}$ and Sheep milk, respectively; (3) Negative control 100\% goat milk; (4) Goat milk adulterated with traces of cow milk; (5) Goat milk adulterated with $1 \%$ cow milk; (6) Goat milk adulterated with 2\% cow milk; (7) Goat milk adulterated with 5\% cow milk; (8) Goat milk adulterated with $100 \%$ cow milk; (9) Goat milk adulterated with 50\% cow milk; (10) Positive control 100\% Cow milk

The PCR tests used, were very sensitive, specific, and reproducible. PCR tests showed a minimum detection limit of $0.01 \%$ (traces) indicating that the analytical assay detected cow milk, even when it was present in small amounts. All the negative controls (water, goat, sheep and donkey milk) didn't give an amplification in the PCR. The sensitivity and the specificity of the method was $100 \%$. The detection limit is very similar to that described by Lopez-Calleja et al. (2005) and Mafra et al. (2007), who reported detection limit of $0.1 \%$ cow's milk. Other authors detected amounts of cow milk as low as 1\% (Maškova \& Paulikova, 2006) and $0.5 \%$ (Bottero et al., 2005; Feligini et al., 2005).

The results of this biosensor were the same when functionalized with both primers and when working only with the forward primer. Similar results were reported by Houhoula et al. (2017) using AUNP's for the identification of horse adulteration in meat products. The studied technique is a useful screening test to detect the presence of cow milk in goat milk, even at traces levels. All the positive samples $(100 \%)$ were found to have the characteristic absorbance peak at $520 \mathrm{~nm}$ (Figure 4) with gradual decrease in absorbance relative to the concentration of genomic DNA present in the test sample (Figure 5). 
A3

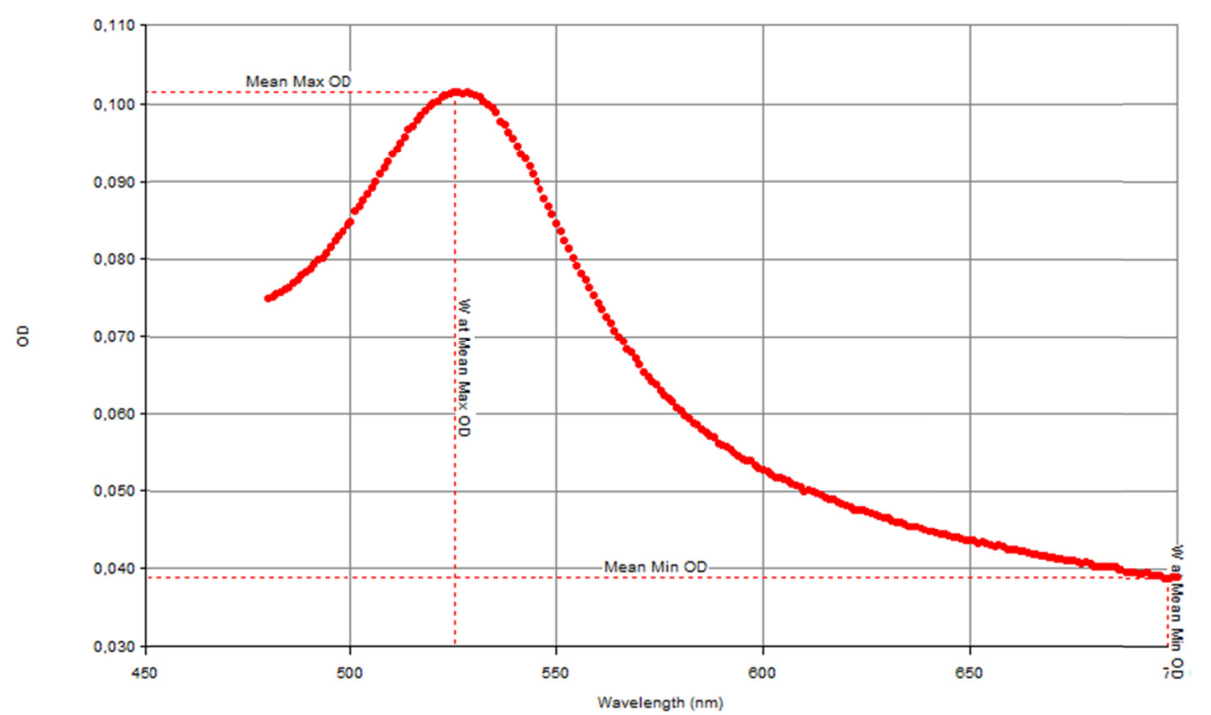

Figure 4. The wavelength at maximum absorbance $520 \mathrm{~nm}$ for Cow milk (Positive control)

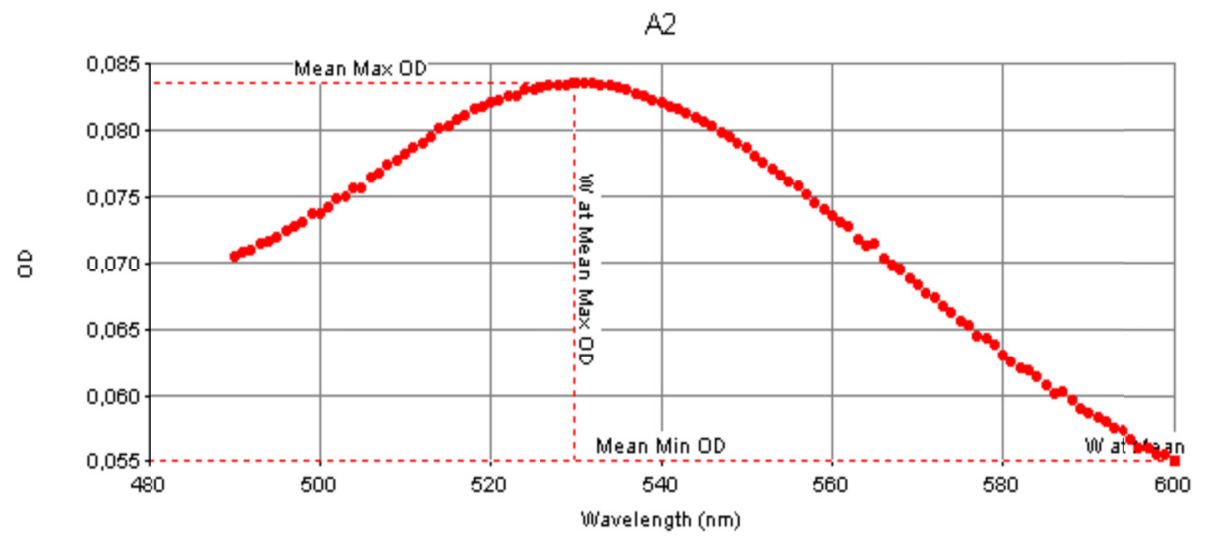

Figure 5. The wavelength at maximum absorbance $530 \mathrm{~nm}$ for Goat milk adulterated with $2 \%$ cow milk

Whereas the negative controls (water, goat, sheep and donkey milk) had a purple colour with the absorbance peak shifted to longer wavelength (Figure 6). The specificity was $100 \%$ (true negative rate). An interesting feature of this assay is that the positive samples even when preserved overnight at room temperature, continue to retain their colour suggesting the long-time stability of AuNP-oligo probe hybridization with the target sequence. This feature is particularly useful for prolonged read-out capability required for high-throughput applications. Therefore, it was confirmed that following this protocol it is possible to find even traces of cow milk in goat milk. The method was repeatable and produced the same results all five times it was performed. The proposed method is a fast, reliable, and cheap for the detection of adulteration of goat milk. The visual results can be further confirmed inexpensively by reliable absorption spectroscopy which incurs only the instrumental cost and cuvettes. 
A8

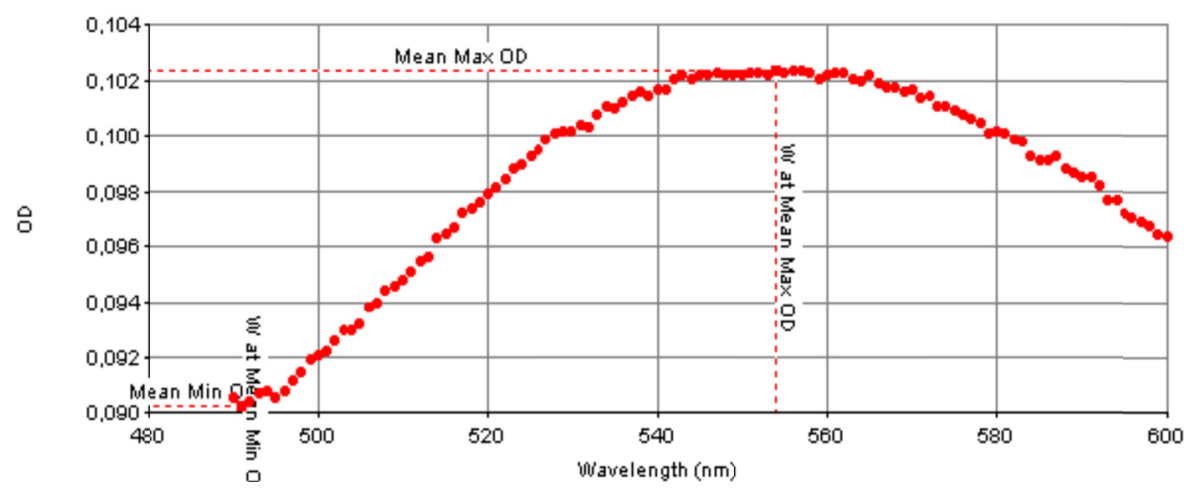

Figure 6. The wavelength at maximum absorbance $554 \mathrm{~nm}$ for Goat milk (Negative control)

Forty (40) samples of commercial goat milk and dairy products were analyzed by the PCR assay. In all of them, the PCR assays amplified the 274-bp fragment expected for cow derived-material. The former fragment indicates the addition of cow milk, considered a twenty percent (20\%) at least adulterant component, in thirty six (36) commercial samples. This means that $90 \%$ of the products tested were adulterated with cow milk. In specific, all the 25 packaged goat milk products $(100 \%)$ and 11 of the goat cheeses $(73 \%)$ were adulterated with cow milk. The rest four (4) samples were found adulterated at a level of approximately 1-5\% again with cow milk.

The same 40 samples were tested with the AuNPs assay method. All the samples gave positive and comparable to the conventional PCR method results (100\% sensitivity, true positive rate). All the 25 packaged goat milk products $(100 \%)$ and the 11 goat cheeses $(73 \%)$ had the the characteristic absorbance peak at $520 \mathrm{~nm}$ and the color remained pink. The four samples that were found positive by PCR with an adulteration of $1-5 \%$ had an absorbance peak at $530 \mathrm{~nm}$ and the color remained pink.

The method provided a semiquantitative information of the target DNA. On the other hand, UV-vis spectroscopy is available in most laboratories and can authenticate the visually identified results of colloidal gold (Verma et al., 2015).

The evaluation of the specificity and the repeatability of the AuNPs method, indicate that it can detect-in a reliable and highly specific manner-a broad spectrum of adulterated samples without cross reactions. The performance of the proposed method proved comparable to that of PCR regarding both the sensitivity $(100 \%$ concordance of positive results) and specificity ( $100 \%$ concordance of negative results).

\section{Conclusions}

The proposed method is a rapid (less than $20 \mathrm{~min}$ ), reliable, and cheap method (4 euros/reaction) for the selective detection of target DNA sequences. It does not need any instrument or surface modification chemistry and directly detects target DNA in non-amplified mixed genomic DNA. The procedure is very simple and relies on the colour change of 20-nm AuNPs following salt addition. The visual indications are solid and can be further confirmed by an inexpensive, widely available, and reliable absorption spectroscopy which incurs only the instrumental cost and cuvettes. The use of absorption spectroscopy increases sensitivity and eliminates any sort of colour-blindness error or ambiguity in visual detection by producing well-defined bands of aggregated and non-aggregated colloidal particles.

\section{References}

Afzal, A., Mahmood, M. S., Hussain, I., \& Akhtar, M. (2011). Adulteration and microbiological quality of milk (A Review). Pakistan Journal of Nutrition, 10(12), 1195-1202. https://doi.org/10.3923/pjn.2011.1195.1202

Ali, M. E., Hashim, U., Mustafa, S., Che Man, Y. B., \& Islam, K. N. (2012). Gold Nanoparticle Sensor for the visual detection of pork adulteration in meatball formulation. Journal of Nanomaterials, 7, Article ID 103607. https://doi.org/10.1155/2012/103607

Ali, M. E., Hashim, U., Mustafa, S., Che Man, Y. B., Adam, T., \& Humayun, Q. (2014). Nanobiosensor for the detection and quantification of pork adulteration in meatball formulation. Journal of Experimental Nanoscience, 9(2), 152-160. https://doi.org/10.1080/17458080.2011.640946 
Ali, M. E., Hashim, U., Mustafa, S., Che Man, Y. B., Yusop, M. H., Bari, M. F., ... Hasan, M. F. (2011). Nanoparticle sensor for label free detection of swine DNA in mixed biological samples. Nanotechnology, 22(19), 195503. https://doi.org/10.1088/0957-4484/22/19/195503

Bohren, C. F., \& Huffman, D. R. (1983). Absorption and Scattering of Light by Small Particles. John Wiley \& Sons, NY.

Borkova, M., \& Snaselova, J. (2005). Possibilities of Different Animal Milk Detection in Milk. Czech Journal of Food Science, 23(2), 41-50. https://doi.org/10.17221/3371-CJFS

Bottero, M. T., Civera, T., Nucera, D., Rosati, S., Sacchi, P., \& Turi, R. M. (2003). A multiplex polymerase chain reaction for the identification of cows', goats' and sheep's milk in dairy products. International Dairy Journal, 13, 277-282. https://doi.org/10.1016/S0958-6946(02)00170-X

Cheng, Y. H., Chen, S. D., \& Weng, C. F. (2006). Investigation of goats' milk adulteration with cows' milk by PCR. Asian-Australasian Journal of Animal Sciences, 19, 1503-1507. https://doi.org/10.5713/ajas. 2006.1503

Darwish, S. F., Allam, H. A., \& Amin, A. S. (2009). Evaluation of PCR Assay for Detection of Cow's Milk in Water Buffalo’s Milk. World Applied Sciences Journal, 7(4), 461-467.

Das, S., Goswami, B., \& Biswas, K. (2016). Milk Adulteration and Detection: A Review. Sensor Letters, 14(1), 4-18. https://doi.org/10.1166/s1.2016.3580

Enne G., Elez, D., Fondrini, F., Bonizzi, I., Feligini, M., \& Aleandri, R. (2005). High-performance liquid chromatography of governing liquid to detect illegal bovine milk's addition in water buffalo Mozzarella: Comparison with results from raw milk and cheese matrix. Journal of Chromatography A, 1094(1-2), 169-178. https://doi.org/10.1016/j.chroma.2005.09.004

EU Science Hub. (2016). European Commission-New monthly report on food fraud and authenticity. Retrieved March 31, 2020, from https://ec.europa.eu/irc/en/science-undate/new-monthly-report-food-fraud-and-auth enticity

Feligini, M., Bonizzi, I., Curic, C. V., Parma, P., Greppi, G. F., \& Enne, G. (2005). Detection of Adulteration in Italian Mozzarella Cheese Using Mitochondrial DNA Templates as Biomarkers. Food Technology and Biotechnology, 43(1), 91-95.

Golinelli, L. P., Carvalho, A. C., Casaes, R. S., Lopes, C. S., Deliza, R., Paschoalin, V. M., \& Silva, J. T. (2014). Sensory analysis and species-specific PCR detect bovine milk adulteration of frescal (fresh) goat cheese. Journal of Dairy Science, 97(11), 6693-6699. https://doi.org/10.3168/jds.2014-7990

Haenlein, G. F. W. (2004). Goat milk in human nutrition. Small Ruminant Research, 51, 155-163. https://doi.org/ 10.1016/j.smallrumres.2003.08.010

Hill, H. D., \& Mirkin, C. A. (2006). The bio-barcode assay for the detection of protein and nucleic acid targets using DTT-induced ligand exchange. Nature Protocols, 1(1), 324-36. https://doi.org/10.1038/nprot.2006.51

Houhoula, D. P., Kouzilou, M., Tzogias, C., Kyrana, V., Sflomos, C., Tsaknis, J., \& Lougovois, V. (2017). Effectual Gold Nanoprobe Sensor for Screening Horse Adulteration in Meat Products. Journal of Food Research, 6(4), 34-39. https://doi.org/10.5539/jfr.v6n4p34

Hurley, I. P., Coleman, R. C., Ireland, H. E., \& Williams, J. H. H. (2004). Measurement of bovine IgG by indirect competitive ELISA as a means of detecting milk adulteration. Journal of Dairy Science, 87(3), $215-221$. https://doi.org/10.3168/jds.S0022-0302(04)73195-1

Kusec, I. D., Samac, D., Margeta, V., Radisic , Z., Vincek, D., \& Kusec, G. (2017). Efficiency of PCR-RFLP and Species-specific PCR for the Identification of Meat Origin in Dry Sausages. Czech Journal of Food Sciences, 35(5), 386-391. https://doi.org/10.17221/243/2016-CJFS

Lahiff, S., Glennon, M., O’Brien, L., Lyng, J., Smith, T., Maher, M., \& Shilton, N. (2001). Species-specific PCR for the identification of ovine, porcine and chicken species in meta and bone meal (MBM). Molecular and Cellular Probes, 15(1), 27-35. https://doi.org/10.1006/mcpr.2000.0336

Lopez-Calleja, I., Gonzalez, I., Fajardo, V., Rodriguez, M. A., Hernandez, P. E., Garcia, T., \& Martin, R. (2004). Rapid detection of cows' milk in sheeps' and goats' milk by a species-specific polymerase chain reaction technique. Journal of Dairy Science, 87(9), 2839-2845. https://doi.org/10.3168/jds.S0022-0302(04)73412-8 
Maskova, E., \& Paulickova, I. (2006). PCR-based detection of cow's milk in goat and sheep cheeses marketed in the czech republic. Czech Journal of Food Science, 24(3), 127-132. https://doi.org/10.17221/3307-CJFS

Mayer, H. K. (2005). Milk species identification in cheese varieties using electrophoretic, chromatographic and PCR techniques. International Dairy Journal, 15(6-9), 595-604. https://doi.org/10.1016/j.idairyj.2004. 10.012

Neumann, C. G., Harris, D. M., \& Rogers, L. M. (2002). Contribution of animal source foods in improving diet quality and function in children in the developing world. Nutrition Research, 22(1-2), 193-220. https://doi.org/10.1016/S0271-5317(01)00374-8

Pesic, M., Barac, M., Vrvic, M., Ristic, N., Macej, O., \& Stanojevic, S. (2011). Qualitative and quantitative analysis of bovine milk adulteration in caprine and ovine milks using native-PAGE. Food Chemistry, 125(4), 1443-1449. https://doi.org/10.1016/j.foodchem.2010.10.045

Poonia, A., Jha, A., Sharma, R., Singh, H. B., Rai, A. K., \& Sharma, N. (2016). Detection of adulteration in milk: A review. International Journal of Dairy Technology, 70(1), 23-42. https://doi.org/10.1111/1471-0307. 12274

Quinten, M., \& Kreibig, U. (1986). Optical properties of aggregates of small metal particles. Surface Science, 172(3), 557-577. https://doi.org/10.1016/0039-6028(86)90501-7

Rance, F., Grandmottet, X., \& Grandjean, H. (2005). Prevalence and main characteristics of schoolchildren diagnosed with food allergies in France. Clinical Experimental Allergy, 35(2), 165-172. https://doi.org/ $10.1111 / \mathrm{j} .1365-2222.2005 .02162 . x$

Salih, M. A. M., \& Yang, S. (2017). Common milk adulteration in developing countries cases study in China and Sudan: A Review. Journal of Advances in Dairy Research, 5(4). https://doi.org/10.4172/2329-888X. 1000192

Sampson, H. A. (2003). Food Allergy. Journal of Allergy and Clinical Immunology, 111(2), 540-547. https://doi.org/10.1067/mai.2003.134

Sato, K., Hosokawa, K., \& Maeda, M. (2003). Rapid aggregation of gold nanoparticles induced by non-cross linking DNA hybridization. Journal of the American Chemical Society, 125(27), 8102-8103. https://doi.org/ $10.1021 / \mathrm{ja} 034876 \mathrm{~s}$

Stanciuc, N., \& Rapeanu, G. (2010). Identification of adulterated sheep and goat cheeses marketed in Romania by immunocromatographic assay. Food and Agricultural Immunology, 21(2), 157-164. https://oi.org/ $10.1080 / 09540100903508683$

Verma, M. S, Rogowski, J. L., Jones, L., Frank, X., \& Gu, F. X. (2015). Colorimetric biosensing of pathogens using gold nanoparticles. Biotechnology Advances, 33(6), 666-680. https://doi.org/10.1016/j.biotechadv. 2015.03.003

Zelenakova, L., \& Golian, J. (2008). Application of ELISA tests for detection of milk and cheese adulteration. Sci. Monograph, SPU Nitra 98.

Zeng, S., Yong, K. T., Roy, I., Dinh, X. Q., Yu, X., \& Luan, F. A. (2011). A Review on functionalized gold nanoparticles for bio-sensing applications. Plasmonics, 6, 491-506. https://oi.org/10.1007/s11468011-9228-1

\section{Copyrights}

Copyright for this article is retained by the author(s), with first publication rights granted to the journal.

This is an open-access article distributed under the terms and conditions of the Creative Commons Attribution license (http://creativecommons.org/licenses/by/4.0/). 